\title{
LENE OTTO
}

\section{BIOGRAFISKE SAMLINGER}

\author{
Subjektivitet, identitet og materielle livshistorier
}

\begin{abstract}
Samtidig med, at man bliver selvbevidst, bliver man en bevidst samler af identitet, idet man projicerer sin væren over i de ting, som man vælger at leve sammen med (Elsner \& Cardinal 1994:3).
\end{abstract}

Mange mennesker gemmer ting, der har livshistorisk betydning. Denne praksis har været anskuet som et led i en personlig udviklingsproces, hvor livet og tidens gang dokumen-teres, det kan være en form for kulturel tvang, hvor selvrefleksion opfattes som en nødvendighed for at kunne fungere i det moderne samfund eller det kan være resultatet af en nærmest ubevidst trang til at materialisere minder. Det at samle på biografiske genstande er under alle omstændigheder anderledes end andre former for samlermani. Biografiske samlinger styres ikke af en ambition om at få en komplet samling, de er ikke skabt for at bevare noget for eftertiden og de bygger ikke på en forudgående klassifikation, men som andre samlinger er de resultatet af en blanding af nostalgi, glemsel og erindring, længsel, dokumentationstrang og vilje til orden. Biografiske samlinger har først og fremmest en identitetsskabende funktion, i modsætning for eksempel til samlinger, der har en erkendelsesskabende funktion.

Biografiske samlinger kan således være en indgang til at forstå den subjektivitet, som folk omfatter deres liv med. Samlingen kan anskues som en livshistorisk fortælling, som ikke behøver at verbaliseres, men som fungerer i kraft af tingenes tilstedeværelse. Enhver samling, hvor lille og ubetydelig den end måtte være, udgør i kraft af dens udvalg, sammensætning og ordensprincipper en personlig fortælling. Ud af de enkelte ting, som er forbundet med forskellige dele af livsforløbet, konstrueres en sammenhængende fortælling. Livets orden eller mønster materialiseres i genstande, som således både er identitetsbærende symboler, erindringsbærere og „aktører“ i skabelsen af biografisk identitet.

Det subjektive, biografisk perspektiv, som jeg i denne artikel anlægger på samlinger, er et forsøg på at forstå følelser og livsanskuelser som noget der dannes i forskellige former for kulturel praksis. Ved at bruge betegnelsen biografiske genstande om de ting, der både henter betydning fra livet, og giver livet betydning betones genstandenes aktive rol-le. De biografiske genstande skal således ikke blot betragtes som passive symboler på li-vets tabte øjeblikke, men ligesom sprogets ord og begreber, konstituerer og konstruerer de virkelighed; de er aktive medskabere af livshistorien. De ting som en biografisk samling består af, er både identitetsbærende symboler, erindringsbærere og identitetsskabere. 
Artiklen er en skitse til hvordan man kan bringe så forskellige forskningsfelter som materiel kultur, erindring, fortællinger, biografisk subjektivitet, og selvteknikker sammen til en forståelse af fænomenet biografiske samlinger og samlere. Da emnet således er materialiserede livshistorier, vil det være relevant med et tilbageblik på den rolle, den materielle kultur hat spillet i kulturforskningen.

\section{Materiel kultur og kulturel erindring}

I den vestlige verden er den materielle kultur traditionelt blevet opfattet som adskilt fra den åndelige kultur. I Danmark var det for eksempel grundlaget for oprettelsen af to forskellige universitetsfag, nemlig etnologi og folkloristik. ${ }^{1}$ Studiet af den materielle kultur indgik traditionelt i større teorier om samfund og civilisation. Uanset om tingene blev gravet op af jorden af arkæologer, indsamlet på ekspeditioner af etnografer eller hjembragt fra bøndernes boliger, klædeskabe og lader af folkelivsforskere, blev de i forskningen på museerne og universitetet fortolket som led i en evolutionær udvikling eller som kilder til diffusionsprocesser. Forskningen baseredes i hovedsagen på tingenes ydre ligheder og var blind over for genstandes forskellige betydning og kulturelle brug. I 1960'erne forlod mange kulturfag de isolerede studier af materiel kultur til fordel for funktionalistiske helhedsstudier. I 1980'erne dukkede genstandsforskningen atter op, men nu i en ny kontekst, hvor den materielle kultur primært blev analyseret ud fra et symbolsk og semiotisk perspektiv. Semiotikkens anskuelse af den materielle verden som en tekst, der kan „læses“ har bidraget til, at tekst-analogien er blevet særdeles udbredt i forskningen i materiel kultur. Der er ingen enkelt forklaring på, at genstandsforskningen er kommet ind i kulturforskningen igen i løbet af 1980'erne, men det er blandt andet foregået i forbindelse med en mere generel forskydning af interessen fra vareproduktion til varekonsumtion. Denne ,nye“ genstandsforskning hentede inspiration både fra den semiotiske tradition (Baudrillard 1996; Hebdige 1979), hvor opmærksomheden rettes mod ,tingenes tale“, og fra den politisk- økonomiske tradition (Bourdieu 1984 [1979]; Appa-durai 1986), hvor det kulturelt bestemte forbrug er i centrum.

Interessen for materiel kultur har dog ikke kun udmøntet sig i semiotisk inspirerede analyser, hvor tingene anskues som tegn, det vil sige som del af et overordnet begrebs-system, men også i interaktionistisk inspirerede analyser, hvor menneskers identitet ikke forstås som noget mennesket iboende, men som noget, der formes gennem omgangen med hverdagens ting. ${ }^{2}$ Konsumtionsforskningen er et godt eksempel på den tendens. Her anskues forbruget af ting som en klassifikationsproces og dermed som del af en tolkende tegnproces, der konstituerer betydning. Konsum handler således ikke primært om behovsopfyldelse, men indgår i et større kommunikationssystem, der samtidig er skabende, fordi det at konsumere er at opdage, at skabe og at bekræfte vores sociale og kulturelle omverden. Ting kan altså også være handlingsstrukturerende, hvilket er en pointe, der kan føres tilbage til Baudrillards arbejder. Han argumenterede for, at forbrug og valg af ting ikke bare er en materiel praksis; det er også en måde at skabe erkendelse på ved at organisere og systematisere tingenes betydning. På den måde kan man sige, at mennesker også skaber deres liv med dets forskellige faser via deres forbrug af ting (og det man vælger fra). En genstands betydning(er) kan således ikke isoleres fra brugen af den. Disse forskellige tendenser kan ses som forsøg på at opløse dualismen mellem 
åndelig og materiel kultur samt subjekt og objekt. Tingene ses i højere grad som selvstændige faktorer i de kulturhistoriske processer end blot som tegn, kilde eller beviser. De materielle genstande har fået en plads i teorierne som aktive skabere af kultur og ikke kun som passive resultater af erkendelses- og tankevirksomhed.

Sammenfattende kan man sige, at interessen har forskudt sig fra relationer, tegn og betydninger til tingenes tingslighed - deres fysiske udformning, materielle sanselighed, anvendelse og påvirkning af menneskers liv. Vigtigt er, at betydning forstås både mentalt og praktisk, ikke bare tingenes symbolske betydning, men hvad mennesker $g \phi r$ med ting, og hvad tingene $g \phi r$ med mennesker. Fokus er med andre ord flyttet fra tingene som betydningsbærere til tingene som aktive deltagere i hverdagens interaktion. Netop dette perspektiv, hvor det er omgangen med tingene - deres rolle i udviklingen af færdigheder, håndelag, kompetencer, viden og subjektivitet kan siges at være det vigtigste nybrud inden for studiet af materielle genstande. Dette brede interessefelt betegnes efterhånden hyppigst som studiet af materiel kultur, hvilket også er den internationalt brugte betegnelse (jf. tidsskriftet Journal of Material Culture, der blev startet i 1995 af blandt andre antropologen Daniel Miller). Betegnelsen „materiel kultur“ frem for „genstandsforskning" signalerer samtidig, at det er kultur og ikke tingenes form og funktion, der er vigtig.

I det hele taget kan der i øjeblikket iagttages en interesse i kulturforskningen for at vende tilbage til det materielle, fysikaliteten og de sansemæssige erfaringer. Mange forskningsprojekter fokuserer i øjeblikket på den informelle tilegnelse af hverdagskompetencer i praksis i en materiel kontekst, ligesom der i studier af materiel kultur og museer findes spredte fors $\emptyset \mathrm{g}$ på at diskutere andre former for sansningers end synssansens betydning for subjektivitetsdannelsen, for eksempel de sensomotoriske og de taktile (Warnier 2001). Der er mange interessante indsigter i disse studier, men der er også en fare for, at et så stærkt fokus på det materielle kan svinge over i en form for essentialisme, hvor den materielle verden opfattes som noget, der eksisterer uafhængigt af mennesket og derfor muligt at betragte adskilt fra den kulturelle betydningstilskrivning.

Interessen for tingenes materialitet præger også flere nyere studier af relationen mellem erindringsgenstande og erindringssteder inden for mange forskellige fag. I den nyere forskning i kulturarv og kollektiv erindring er det således en præmis, at ting har en symbolsk såvel som en fysisk evne til at forbinde fortid og nutid. Ligeledes er det blevet et udbredt synspunkt, at det at samle, gemme og bevare samtidig er at skabe noget, for eksempel fortiden, Historien eller en særlig identitet. Følgelig må erindring begribes som en individuel eller en politisk social konstruktion (Nora 1984; Halbwachs 1980; Gillis 1996; Lowenthal 1993). Den optagethed af erindringskultur, erindringsfællesskaber og personlige erindringsgenstande, kan ses som udtryk for en forskningsmæssig forskydning fra det positivistiske og dokumenterende til det kulturelle og personlige.

Denne omsiggribende interesse for subjektivitet i kultur- og samfundsvidenskaberne spiller sammen med den ovenfor beskrevne interesse for den materielle kulturs aktive rolle og erindringer som konstruktion. I denne artikel er interessen koncentreret om en særlig form for subjektivitet, nemlig det man kunne kalde en biografisk subjektivitet. Tanken er, at subjektiviteten også formes i den praktiske omgang med ting, der knytter an til livshistorien. Sådanne personlige erindringsgenstande har den egenskab, at de kan gemmes væk, men fremtages når som helst, bruges, ordnes, arrangeres og iscenesættes. Det er selve det at de indgår i dagliglivets praksis, der gør dem til både erindringsbarere og erindringsskabere. 
Begreber som erindringssteder og erindringsgenstande indeholder dog både en kollektiv og en individuel side. På den ene side fungerer erindringsgenstande som konventionelle symboler, og på den anden side er de bærere af privat betydning. De to betydninger kan ikke isoleres, men bestemmer hinanden indbyrdes. Det subjektive må således ses som en del af samfundets historie. En sådan forståelse indebærer, at mennesket bliver til et individ $i$ og gennem samfundet og ikke på trods af det. Denne forståelse er i modsætning til den oplysningsfilosofiske tradition, hvor man har tænkt individet som et autonomt subjekt, der eksisterer løsrevet fra natur og samfund. Samfundet og naturen ses som begrænsninger for individet. En biografisk subjektivitet repræsenterer således et socialt forhold og ikke blot et individs følelsesmæssige erfaringer af levet liv Det er en vigtig pointe for at undgå en ahistorisk og kulturløs optagethed af det personlige og private. I det følgende vil jeg derfor argumentere for, at den biografiske beskæftigelse i form af biografiske samlinger er et historisk og kulturelt fænomen.

\section{Samlermani som kulturel praksis}

Antropologer, etnologer, sociologer og museologer har i forskellige sammenhænge diskuteret samlemaniens etnografi (Schlereth 1992). Begæret efter ting og samlerlidenskab har været genstand for adskillelige studier, hvor årsagerne til samlertrangen og forskellige samlestrategier har været i fokus (Akin 1996; Baudrillard 1994; Clifford 1988, 1990; Elsner \& Cardinal 1994; Kirshenblatt-Gimblett 1989; Pearce 1995; Rogan 1996; Schlereth 1992; Stewart 1984). Samleri og gemmeri viser sig at have mange former og opfylde forskellige funktioner, men tilsyneladende er der en konsensus om, at samlinger repræsenterer menneskers trang til at ordne, kategorisere og systematisere - ,to make the world one's own“ (Clifford 1988:221). Til gengæld er der uenighed om, hvorvidt det at samle på ting er en særlig praksis, som karakteriserer den vestlige kultur og identitetsdannelse eller om alle mennesker til alle tider, har udvalgt særlige ting, som giver mening til deres liv. Spørgsmålet er om det at tilskrive udvalgte materielle genstande en biografisk dimension er en almenmenneskelig eller en kulturelt bestemt praksis?

Janet Hoskins, der er antropolog, argumenter for det første synspunkt i bogen Biographical Objects (1998). Hendes intention er at forstå ,den narrative konstruktion af selvet ved hjælp af genstande“ (Hoskins 1998:24). Udgangspunkt er en frustration over ikke i forbindelse med feltarbejde i Østindonesien hos kodi-folket at få de forventede livshistorier, som mange antropologer ellers kan have en forestilling om findes hos folk, færdigformede og parate til at blive indsamlet og transskriberet. Dermed går hun ind i debatten om, hvorvidt narrativer og menneskers ,selv“ er essenser, der bare kan findes. Når Hoskins stillede spørgsmålet ,fortæl mig om dit liv“, fik hun fra mændene en opremsning af udførte bedrifter og fra kvinderne en fortælling om deres børn. De havde tilsyneladende ikke en biografisk subjektivitet. De var modstræbende og tavse, når de blev bedt om at tale om sig selv, men de var særdeles dygtige historiefortællere, når de skulle tale om deres personlige ejendele. Det opdagede hun ved en anden lejlighed, hvor hun interview-ede de samme personer om udveksling af ting og om rituelt betydningsfulde genstande. Det viste sig at være indgangen til folks personlige erfaringer og subjektivitet.

Det var ikke muligt at holde tingenes historie adskilt fra personernes livshistorier i interviewsituationen. Derfor blev Hoskins mere og mere optaget af personlige symboler 
og tings idiosynkratiske betydninger. Hun begyndte at se tilbøjeligheden til at skelne skarpt mellem personer og ting som kulturelt specifik. Konklusionen blev, at der kan findes et er et biografisk indhold i historier, der ellers overfladisk set handler om andre ting end selvet: „når befolkningen berettede deres historier, brugte de tingene autobiografisk, som hjørnestene i historien om dem selv, som et hjælpemiddel til at definere personlig identitet og seksuel identitet" (op.cit.:4). Det antydes endvidere, at genstandenes form kan have betydning. For eksempel bemærker hun, at de biografiske genstande ofte havde form som beholdere, for eksempel en betelsack eller en tromme, det vil sige de var hule, hvorved de nærmest fungerede om ,erindringskar“, der holdt noget inde, og dermed noget andet ude.

Bogen kan ses som et fors $\emptyset \mathrm{g}$ på at forstå, hvordan identiteter og biografier formes omkring genstande i et samfund, der ikke er blevet ,,psykologiseret“ i en konfessionel tradition. Selvom der ikke har været en kristen kirke og siden en række psykosociale videnskaber til at forme menneskers vilje til at skrifte og bekende, er trangen til at skabe en historie ud af sit liv, alligevel tilstede. Altså et argument imod, at disse samfund (endnu) ikke er i besiddelse af idéer om individualitet. For hende er trangen til skabe sit selv med afsæt i en livshistorie universel; den kommer bare ikke alle steder til udtryk i en vilje til at finde sandheden om selvet, men også i den praktiske omgang med ting. Mennesker i Melanesien er ligesom vestens mennesker i stand til at skelne mellem ting og personer, at erfare biografisk og opbygge en individuel subjektivitet. ${ }^{3}$

Hoskins ser det indonesiske samfund, som en ekstrem modsætning til det moderne forbrugssamfund, hvor forbrugerens egen biografi ikke investeres i tingene, og hvor de masseproducerede, standardiserede og dermed erstattelige ting berøver den enkelte ,ethvert ikon for individualitet“. I kontrast hertil står kodifolket, hvor ,ting omgives med en særlig betydning, både i den kollektive repræsentation af fortiden og i den individuelle, biografiske erindring“ (op.cit.:9). Den vigtigste forskel mellem den vestlige kultur og den indonesiske er ifølge Hoskins, at vestens biografiske genstande ofte er mere direkte repræsentative. I stedet for ting bruger vestlige individer portrætter til at repræsentere til-knytningen til forfædrene, i stedet for for eksempel at en teen repræsenterer længslen efter at blive kompletteret af en partner, bruger unge i vores kultur billeder af popidoler, og i stedet for at udleve følelser ved at tromme, synge eller danse endevender vi dem hos en terapeut eller i dagbøger og erindringer. Metaforer, ikoner, symboler og dermed ting spiller altså en mindre rolle i vores kultur, mener Hoskins. Overensstemmelsen mellem tingen og det, den skal repræsentere, er således visuel, mens den i Indonesien skal etableres verbalt - ,de konstruerer et narrativt selv gennem tingenes metaforiske sprog, og de anerkender, at aspekter af selvet kan forhandles på forskellige måder i udvekslinger og mellem generationer“ (op.cit.:191). Hendes analyse bygger på en skelnen mellem genstande, der er masseproducerede og dermed har vare-karakter og genstande der er produceret af - eller under overvågning af ejeren selv. De to former for genstande adskiller sig ved form, arbejde og alder.

Hoskins tolkning af kodifolkets biografiske genstande som et tegn på selvrefleksion kan diskuteres, men den pointe, at materielle genstande ikke blot er metaforer for selvet, men en krumtap for eftertanke og introspektion, et redskab til selvbiografisk selv-op-dagelse og en måde at lære sig selv at kende på, er væsentlig. Trods de mange gode og inspirerende eksempler og overvejelser, finder jeg hendes sammenligning mellem melanesiske og vestlige samfund præget af en „omvendt etnocentrisme“. Hendes store viden 
om kodifolket opvejes ikke af en tilsvarende viden om vestlig biografisk praksis. Hun lægger op til at begrebet ,biografiske genstande“ nærmest er irrelevant i vestlig kultursammenhæng. Alligevel accepterer hun, at

Selvfølgelig udtrykker amerikanere ofte deres identitet ved hjælp af genstande, og de kan også vælge at fortælle deres liv gennem udvalgte tings optik. Således ville det, som en ren tankekonstruktion, være interessant at forestille sig, hvordan idéen om biografiske gen-stande kunne rejse tilbage til mit eget samfund, og hvilke kontraster, der ville være (op.cit.:190).

Selvom det ikke er det amerikanske samfund, jeg beskæftiger mig med i det følgende, vil jeg ikke lade overvejelser om genstandenes betydning for identiteten og subjektiviteten forblive rent spekulative, men gå videre med sådanne eksempler, som Hoskins efterlyser, idet jeg antager, at det ikke en fremmed tanke for det vestlige individ at give sine personlige erfaringer og oplevelser en materiel form. Og i modsætning til Hoskins, vil jeg i det følgende argumentere for at „kommercielle ting (eller gaver, arvestykker, slægtsrelikvier)“" (op.cit.:11) netop har en særlig tilbøjelighed til at blive knyttet til den personlige biografi, uanset deres varekarakter.

Endvidere er tesen, at det er noget specielt for vestlige samfund, at personbegrebet eller subjektiviteten er knyttet til den individuelle livshistorie, ikke fordi man ikke også har været optaget af selvet i andre kulturer, men fordi der findes en mangfoldighed af personopfattelser, der ikke nødvendigvis er afhængig af den individuelle livshistorie, men lige så vel kan være bestemt af tilhørsforholdet til familie, slægt, erhverv eller stamme. I vestlig kultur derimod er tid, historie og udvikling noget meget centralt for selvforståelsen. Det er netop udviklingstanken der ligger i begrebet biografi, og den er historisk specifik. Selve ordet bio-grafi (livs-beskrivelse) optræder først i de store europæiske sprog såvel som det danske i tiden omkring 1800.

\section{Biografiske ting - biografiske fortællinger}

Den biografiske subjektivitet og praksis er en side af den moderne identitet, der omfatter individets evne og vilje til at forstå, erfare og evaluere sig selv i et livsforløbsperspektiv. Når mennesker er i stand til at forestille sig selv som subjekt for en biografi - en livs-historie, at udnytte erindringen til at gøre denne biografi stabil og at anvende bestemte begreber og forklaringer i forsøget på at forstå sig selv, kan man tale om en biografisk subjektivitet. Det er noget, som samfundsudviklingen med dens individualisme og disciplinære tidsopfattelse skabte grundlag for, og som de verdslige stater i 1800-tallet udviklede eksperter og professioner omkring.

Den franske historiker Alain Corbin (1987) har konstateret, at det netop er i løbet af 1800-tallet at individualiseringen, det vil sige fornemmelsen af individuel identitet, får sine særlige materielle udtryk for eksempel i form af initialer på personlige ejendele, fremkomsten af visitkort og personlige lommebøger, udbredelsen af spejlet i alle samfundslag, og ikke mindst det personlige portræt med dets stereotype positurer. Det er og-så på dette tidspunkt, at folk begynder at samle på disse ting:

...folk på ethvert samfundsmæssigt trin begyndte at samle fotografier, udklip, brudekjoler, 
buketter og brudekranse. Disse håndlavede kostbarheder blev gemt væk sammen med juridiske dokumenter og militærpapirer som en skat af dydige souvenirs, der blev værdiløs efter ejerens død (Corbin 1987:547).

Mængden af private papirer, rejsesouvenirs, miniaturer, stambøger, poesibøger og fotografialbum voksede. Private opbevaringssteder i boligen som kister, skrin, æsker, brevmapper og album blev nødvendige. Personlige minder blev i løbet af 1800-tallet også gjort til en kommerciel handelsvare i form af for eksempel hårarbejde, mindevers, kunstnerisk udførte æsker med påtrykt „Souvenir“ samt diverse pynte- og brugsgenstande med inskriptionen: Til Erindring.

Den rene samlermani var selvfølgelig først og fremmest typisk for borgerskabet. Det var ikke ualmindeligt at lave private museer i hjemmet, hvor samlingerne både indeholdt værdifulde samlerobjekter, der udtrykte rigdom, eller personlige souvenirs, der udtrykte en eksklusiv selvbevidsthed. Først i slutningen af 1800-tallet kan man tale om en demo-kratisering af impulsen til at samle. Tilbøjeligheden til at samle materielle minder om egen og familiens livshistorie blev endnu mere udbredt i det 20 . århundrede. Det tolkes ofte, blandt andet af den amerikanske historiker John Gillis, som en individuel, mytologisk oprustning i en tid, hvor den personlige identitet såvel som „familien“ er sårbar: „Vores trang til at repræsentere os selv har forvandlet vores dagligstuer til familieportrætgallerier og vores lofter til arkiver. Vores boliger er mini-museer fyldt med arvestykker, minder og familie-souvenirs" (Gillis 1996:xvi).

Sammenfattende kan man sige, at det var i løbet af 1800-tallet, at en almen evne til på analytisk afstand at forholde sig til sit eget liv som et objekt afgrænset fra omgivelserne, udvikledes. Det kan ses som en ny humanistisk og hermeneutisk forståelse af individet, men også som en videnskabeliggørelse eller en verdsliggørelse af sjælen. Evnen til selvrefleksion udvikledes også gennem interaktionen med ting.

Ting, der samles og følger én gennem livet, er ikke bare tegn og symboler; de er en integreret del af subjektiviteten og selvforståelsen. Deres værdi ligger i deres livshistorie; de er spor og derfor ikke bare hverdagslige objekter men skatte. Tingenes sanselige overflade $\mathrm{g} ø \mathrm{r}$ fortiden levende og tilstedeværende via den fysiske håndtering af tingene og kropskontakten når de arrangeres, kæles med, holdes ind til kroppen, kysses. Tingenes permanente tilstedeværelse betyder, at vi kan kigge på dem, røre ved dem, føle på dem og dermed etablere og vedligeholde en følelse af sammenhæng i livet, som ikke nødvendigvis er lineær eller kausal. Frem for en begrebsliggørelse af fornemmelser og følelser, kan man tale om en tingsliggørelse. Omgangen med ting er en måde at kropsliggøre erfaringer og levet liv og som dermed gør ellers immaterielle erindringer praktiske og konkrete. Fortiden bliver i bogstaveligste forstand håndgribelig .

\section{Samlinger, selvteknikker og subjektivitet}

Begreberne livshistoriske genstande eller biografiske ting bruges, fordi tingenes betydning hentes fra ejerens egen livshistorie. Den biografiske værdi er usynlig for andre, ja, selv genstandene er ofte "usynlige“, for de lever deres liv gemt væk i skuffer, syskrin, mapper og kasser. I princippet kan alle ting fungere som erindringsgenstande, men der findes særligt mange personlige erindringsgenstande blandt de ting, der har direkte forbindelse til livets højtider. Det kan for eksempel være indrammede mindevers, gratula- 
tionskort, indbydelser, bordkort etcetera fra fester ved livets højtider. Eller medaljoner med hårlokker og fors $\varnothing l v e t$ leget $\varnothing j$. Deres værdi er kun inden i den person, der gemmer. Men også privatsfærens nostalgiske minder med fotografier, souvenirs og personlige dokumenter finder vej til det offentlige rum - museer og arkiver. Her bliver de ofte splittede og indgår i helt andre samlinger, ordnet efter andre principper. Tingene fremstår som mere eller mindre tilfældige efterladenskaber. Derfor forstår man ikke de biografiske samlinger alene ved en semiologisk tilgang. De biografiske ting er ikke bare et symbolsk sprog, for de ting, som folk gemmer igennem et livsforløb, bærer ikke et budskab, som nødvendigvis skal forstås af andre end ejeren selv. At samle på minder er at transformere ydre omstændigheder til indre - de ydre oplevelser bliver til indre personlig kerne.

Mennesker der samler på biografiske ting er måske ikke bevidste om, at de er involverede i en subjektivitetsskabende proces, men betragter man disse aktiviteter med Michel Foucaults $\varnothing j n e$, er de engageret i selvteknikker, der producere subjektivitet. Foucault argumenterede for, at selvrefleksion og selvfortolkning skal opfattes som en teknik (Foucault 1999 [1980]). Vi er tilbøjelige til at tænke teknikker som noget der involverer instrumenter, men Foucault taler om det som almindelige former for praksis og omgang med ting. Således kan man tale om selve det at samle på biografiske ting, pakke dem i kasser, arrangere på hylder og i skuffer, sætte i album, skrive små sedler osv. som en selvrefleksiv teknik. Den er teknisk i den forstand, at selvet eller subjektiviteten ikke formes gennem abstrakt viden, men gennem sensomotorisk erfaring og omgang med ting. Man kunne kalde dem kropsliggjorte erfaringer. Pointen er, at identiteten skabes ved mennesker egne aktiviteter, men disse er igen formet af de selvteknikker, som er stillet til rådighed eller påtvunget $i$ et givet samfund.

Selvteknikkerne, for eksempel det at samle på biografiske ting, er således med til at skabe følelsen af være noget særligt - et individ. Det næste spørgsmål er så, hvordan tingene bearbejder og former selvet helt konkret? Hvad er det for mekanismer? Det er jo et spørgsmål, som psykologien traditionelt har beskæftiget sig med. Nogle psykologer peger på, at vores selvbevidsthed udvikles i det praktiske møde med andre subjekter i en materiel verden (fx Piaget 1992). Tingene fastholder og styrer erindringen i en dobbeltproces, hvor man både udvælger ting som minder, men samtidig er disse udvalgte ting med til at strukturere og forme erindringen. På den måde er der tale om gensidig proces, hvor vi ordner tingene omkring os, og samtidig ordner tingene vores liv (Miller 1994:402). Følelser, oplevelser, erfaringer og viden ligger gemt $i$ selve tingen.

\section{Relikvier, relikter og erindringsgenstande}

Biografiske genstande refererer til øjeblikke af lykke eller ulykke, der har sat skel i en personlige livstid, eller til mennesker, der har betydet noget særligt. ${ }^{4}$ Sådanne erindringsobjekter binder fortid og nutid sammen, og gør fortiden nærværende i nutiden. Ting bruges således som markeringspunkter i livscyklus, idet denne sammenkobling mellem ma-terielle udtryk og alderstrin både kan fungere som kollektive periodiseringer $\mathrm{i}$ de individuelle livshistorier, og helt privat og personligt, hvor tingene bliver ,historiens knagerækker“ (Löfgren 1992:270), når man skal (re)konstruere sin livshistorie. Ting markerer overgange og kan fungere som en ledetråd gennem livet. Man kan også sige, at tingene giver vores livshistorie fysisk liv og overvinder modsigelsen imellem en fortid, 
der er forbi, og den nutid, hvori tingene overlever. Det er ved at forholde os til tingene, at vi sætter vores nutidsbevidsthed i forhold til historien. Genstandene fortæller så at sige livshistorien med historier, idet hver genstand også har sin egen historie - livshistorie.

Det ser ud som om, at der i den vestlige verden har været en vis kontinuitet i folks trang til at samle på ,forsteninger“" af noget, der først og fremmest er mentale - og følelsesmæssige fænomener. Det er tilsyneladende de samme følelser og erfaringer i form af ting, vi samler på, nemlig sentimentale følelser i forbindelse med kærlighed, børnefødsler, venskaber, forelskelser og tab. Bestemte typer af genstande appellerer tilsyneladende til disse følelser, således at de ting vi gemmer af private grunde, fordi de associerer til en særlig person eller begivenhed, samtidig er en slags fælles metaforer.

Når det drejer sig om livshistoriske genstande, kan man ikke komme uden om nostalgien eller sentimentaliteten. Nostalgi er et sentimentalt og idealiseret syn på fortiden, både ens egen, og de mere generelle forestillinger om individets fortid som ligger i begrebet barndom. Nostalgi er at laenges mod noget, som har været, men det kan diskuteres, om nostalgi er en dyrkelse af fortiden, eller det er en måde at undgå at forholde sig til den på, ved at fastfryse den i stivnede, tidløse øjeblikke og putte den i æsker, skuffer og album. Nostalgi forbindes ofte med vestlig kultur, men selve idéen om, at man kan komme i kontakt med det uopnåelige eller mistede gennem materielle genstande, for eksempel amuletter eller helgenlevninger, findes i alle kulturer.

De biografiske ting, som den enkelte samler på, har helt forskellig beskaffenhed alt efter deres relation til personens samlede livsforløb. Man kan sige at livshistorie biografien er ordnen, der bestemmer hvilket betydningsindhold tingene tillægges. Jeg har i andre sammenhænge fundet det relevant at skelne mellem biografiske relikter, som er overlevede brugsting fra en persons liv, og biografiske relikvier, som bevidst er gemt, fordi de symboliserer særlige $\emptyset$ jeblikke af livsfylde eller mistede personer. Denne sondring er inspireret af semiotikkens definition af forskellen mellem metafor som er et rent symbol - et relikvie, og metonym som er et levn - et relikt (Otto \& Pedersen 1998).

De biografiske relikter er ting, der har en direkte reference til begivenheder i livet - de er levn eller rester. De er vidnesbyrd om, at ejermanden har levet og erfaret. De indgår i biografiske samlinger fordi de besidder en kraft, blot fordi de var til stede i et bestemt $\varnothing$ jeblik i fortiden, som er mistet for evigt, men som tingen kan etablere en fysisk tilknytning til. Det kan være præmier, jubilæumsgaver og andre ting, der symboliserer overgange og vendepunkter i livet. Den type person, der gemmer ting fra livet som dokumen-tation af livets gang, er en slags arkivarer i forhold til deres eget livsforløb. De biografiske relikvier derimod er ting, der først og fremmest er metaforer eller symboler. Det er det narrative, der knytter dem til livshistorien, og tilskriver dem kvaliteter, der gør dem til uundværlige livsledsagere, ligesom religiøse legender og myter tilskriver religiøse relikvier magiske egenskaber. Følgelig bliver en ting først et relikvie for livshistorien, når den bliver tilskrevet en særlig emotionel eller dannelsesmæssig betydning. Folk samler både på biografiske relikter og relikvier fordi de kan bringe ejeren/samleren i kontakt med fortiden og således medvirke til at skabe helhed og kontinuitet i livet. Tingene repræsenterer fremtidens fortid, og ved at samle på dem, skabes bevidst biografiske begivenheder, som bliver fremtidens ,minder“. Det er ikke alene den aktuelle erfaring, der giver tingene værdi, men også bevidstheden om, at den i fremtiden har værdi som forbindelsesled til den tabte fortid.

I modsætning til den del af genstandsforskningen, der anskuer genstandene ud fra et kommunikationsperspektiv, hvor tingenes funktion er at blive „læst“ og identificeret af andre i det sociale liv, ses omgangen med genstandene her som et led i strategier $\Phi$; 
at forstå sig selv. Dette perspektiv er blandt andet blevet udviklet af dem amerikanske fol-klorist Barbara Kirshenblatt-Gimblett (1989), som i en artikel beklager, at forskere ikke har studeret de måder, folk bevarer, samler, gemmer og arrangerer deres ting på, således at tingene skaber en mening og betydning for personen selv. Hun argumenterer for, at tingene ikke bare er efterladenskaber, men at de aktivt koder erindringen, og ,fortæller" livshistorie. Hun påpeger endvidere, lige som Hoskins, at når det drejer sig om erindringsgenstande, kan formen i visse tilfælde lede på sporet af indholdet. Formen påvirker den måde, vi tænker og erkender på. Et eksempel på dette er vores kulturs fascination af miniaturer (for eksempel ofte en hobby for ældre, der erindrer sig hjemstavnen eller barndommen gennem at kreere miniaturer), hvor det er formen i sig selv, der skaber vores følelse af nostalgi - længslen efter inderlighed (Stewart 1984). Alligevel skal man også være opmærksom på, at den samme fysiske ting som for eksempel en lok hår, kan have vidt forskellig betydninger, og i sådanne tilfælde er det ikke formen, der er kilde til følelser. Betydningen er både kulturel og livshistorisk, og det ville være forkert at gå ud fra, at hårlokker pr. definition er nostalgiske objekter. Folk kan have andre grunde til at gemme dem. Disse grunde kan det være svært at komme tæt på, for man vil ofte havne i psykologiseringer. Til sidst vil jeg derfor præsentere en anden tilgang, hvor biografiske samlinger anskues som resultatet af bagvedliggende ordner, som gør dem meningsfulde.

\section{Biografiske samlinger - biografiske fortællinger}

Biografiske samlinger er i sagens natur individuelle, men der er også kulturelt bestemte mønstre i vores måder at samle på og dermed skabe konkrete fortællinger. Når man skal „læse“ konkrete biografiske samlinger, vil jeg argumentere for, at tidsopfattelsen er et centralt element. Det gælder i for sig for alle typer af fortællinger, uanset om de skrives, berettes eller komponeres med ting. Opfattelsen af tiden som linear, cyklisk eller fragmentarisk vil ofte, i hvert fald i vores kultur, være den orden der tilskriver erfaringer og oplevelser en bestemt betydning. For den moderne opfattelse af tid, hvor fortiden er noget, der går tabt, er baggrunden for, at ting kan fungere som forbindelsen til det tabte. I et cyklisk tidsperspektiv ses den enkeltes liv som led i en kontinuerlig slægtskæde, mens et lineært tidsperspektiv indebærer, at den enkeltes liv ses som et produkt af brud, forandringer og personlige erfaringer. Et tredje perspektiv er at opfatte tid som øjeblikke, idet liv ikke tænkes hverken kronologisk eller cyklisk, men erindres som øjeblikke af særlig livsfylde. De tre samlertyper er blevet kaldt dokumentaristen, forvalteren og nostalgikeren (Otto \& Pedersen 1998).

I deres forskellige biografiske samlinger ligger der således indbygget en biografisk fortolkning i de enkelte genstande. De er tilskrevet betydning, som løfter dem ud af tidens strøm og over i en fortælling; en livshistorisk fortælling: Dokumentaristen samler på ting, der dokumenterer livsforløbet som et fremadskridende kronologisk forløb. Samlingen repræsenterer en fortælling om livet som bestående af overgange mellem faser i livsforløbet. Den kronologiske repræsentation af livet kan relateres til begivenheder af familiemæssig art, for eksempel bryllup, børnefødsler og mærkedage i forbindelse med ægteskab og børnenes opvækst, som det viser sig ofte at være tilfældet for kvindernes vedkommende, eller de kan være af arbejdsmæssig art, for eksempel uddannelse, for-fremmelse og jubilæer på arbejdspladser. Således er dokumentaristen 
den systematiske samler af genstande og helheder, enten fra eget liv (oftest mænd) eller fra andres (oftest kvinder). Biografiske genstande, der repræsenterer denne samlertyper er lejlighedssange, mindevers, eksamensbeviser og souvenirs fra fester i form af bordkort, bordpynt og lejlighedssange. Forvalteren som samlertype gemmer genealogiske objekter om slægtsrelikvier og arvestykker, der spinder en tråd mellem generationerne. Tingene er ikoner, hvis funktion er at fremkalde en fornemmelse af kontinuitet mellem den enkeltes livsforløb, på tværs af generationerne. Identiteten styrkes ved et tilhørsforhold, at være del af og underlagt et fællesskab. Tingene gør det muligt for det enkelte individ at anskue sit liv som et led i en ubrudt slægtskæde, hvor slægt skal følge slægters gang. Samlingerne giver det enkelte livsforløb en nærmest cyklisk karakter, som af mange opfattes som noget meget efterstræbelsesværdigt, ofte formuleret som et $\emptyset$ nske om at slutte ringen. Tingene fortæller således om slægtens sammenhold og materielle ansvar for hinandens liv. Jo flere generationer, jo højere status. Det enkelte individ bliver på en måde en forvalter, der gennem arv får overdraget genstanden i en afmålt periode for derefter at give den videre. Slægtsnavne eller slægtssymboler kan været en del af genstanden, for eksempel navnetrækket på bøndernes brudekister eller adelens våbenskjolde og epitafiebilleder. Man kan sige, at slægten får eksistens og bliver „synlig“ ved kontinuerligt at blive reproduceret i menneskelig praksis. Nostalgikeren samler på ting der fortæller om følelsesfyldte øjeblikke af sorg og smerte - lykke og glæde. De er forstenede længsler, idet nostalgi er længslen efter en anden tid og et andet sted. Disse er i sagens natur personlige og stærkt individuelle, men de biografiske genstande er samtidige kulturelle ikoner som hårlokker, pressede blomster og fotografier, som materialiserer et $\varnothing j$ jeblik i tiden. For som Susan Stewart skriver „,Fotografiet som souvenir er en logisk forlængelse af den pressede blomst, bevarelsen af et $\varnothing$ jeblik i tiden ved reduktion af de fysiske dimensioner og en korresponderende vækst i betydning ved anvendelse af narrativer" (1984:138). Selvom følsomhed, nostalgi og intimitet er en individuel „,trang“ og genstan-dene bliver tillagt individuelle betydninger, hører disse følelser til i en bestemt epoke, et bestemt socialt lag og er kønsspecifikke.

Eksemplerne er et forsøg på at vise, hvordan den materielle kultur kan bruges til at forstå, hvordan erindring og subjektivitet skabes ved hjælp af ting. Pointen er, at den materielle kultur ikke refleksionsløst skaber identitet, som det af og til postuleres i konsumtionsforskningen. De bevidst samlede biografiske ting, gør det muligt for os at reflektere historisk over vores eget liv; de tvinger os til eftertanke og skærper vores bevidsthed om de valg vi har gjort. Mennesker bruger aktivt af deres egen livshistorie til at gribe nutiden and på en fornuftig måde. Således fungere de biografiske ting som materia-liserede erfaringer, og er ikke bare en nostalgisk forvaltning af minder. De tvinger os til at reflektere over livet og fastholde de høstede erfaringer. Argumentet er, at genstandes betydning ikke kan isoleres fra brugen af dem. Tingene er ikke et spejlbillede af selvet. Det „selv“, vi vil fastholde eller finde gennem genstandene, eksisterer ikke på forhånd, men $i$ kraft af dem. Tingene symboliserer ikke bare passivt, men er aktivt konstituerende. Omgangen med tingene er en del af den subjektivitetsskabende proces, det vil sige skabelsen af et selv som en person med en unik karakter og en individuel biografi. Den biografiske subjektivitet kan altså have andre former end den traditionelle, selvrefleksive selvbiografi, den kan også konstitueres, forvaltes og forandres ved hjælp af biografiske samlinger. 


\section{Noter}

1. Faget Europæisk etnologi på Københavns Universitet hed indtil 1971 Materiel folkekultur.

2. Symbolic interactionism (symbolsk interaktionisme) er en teoretisk skole, der referer til den amerikanske antropolog George Herbert Mead, som studerede identitet i en materiel kontekst. I sin teori om identitet påpegede han, hvordan materielle genstande kan fungere som „den anden“ i en selvrefleksiv proces som forudsætning for selvidentitet.

3. Det universalistiske synspunkt er selvfølgelig ikke repræsentativt for antropologien som sådan. Hoskins' synspunkt er først og fremmest en reaktion mod en anden antropolog, Marilyn Strathern, der ikke mener, at individualitet er universel, for melaneserne er ikke ,individuals“ - det vil sige udelelige, men snarere „dividuals“, hvis adskilte dele cirkulerer frit, fordi der ikke findes en doktrin om identitet som en enhed. Det er i selve udvekslingen af ting (gaver) at personen konstitueres. Deres identitet cirkulerer gennem tingene. Hoskins er enig i, at det analytiske begreb „partible personhood“ (partiel personlighed) er meningsfuldt, men hun ser det som sin opgave at kvalificere det til brug på det individuelle livs niveau - i relationen mellem biografi og ting, det vil sige hvordan tingene - ,som ‘dele af personen' kan organiseres narrativt for i det mindste at sikre en midlertidig illusion om sammenhæng" (Hoskins 1998:24).

4. De begreber der udvikles i det følgende er oprindelig blevet til i forbindelse med udarbejdelsen af et idéoplæg til en permanent udstilling på Nationalmuseet i Brede i 1995, i samarbejde med Lykke Pedersen.

\section{Litteratur}

Akin, Marjorie

1996 Passionate Possession: The Formation of Private Collections. I: D. Kingery (ed.): Learning from Things. Method and Theory of Material Culture Studies. Washington and London: Smithsonian Institution Press.

Appadurai, Arjun (ed.)

1986 The Social Life of Things. London, New York: Cambridge University Press.

Baudrillard, Jean

1994 The System of Collecting. I: J. Elsner \& R. Cardinal: The Cultures of Collecting. London: Reaktion Books.

1996 The System of Objects. London: Verso.

Bourdieu, Pierre

1984 [1979] Distinction. A Social Critique of the Judgement of Taste. London: Routledge \& Kegan Paul

Clifford, James

1988 On Collecting Art and Culture. I: J. Clifford: The Predicament of Culture. Cambridge, Mass.: Harvard University Press.

1990 Sich selbst sammeln. I: G. Korff \& M. Roth (eds.): Das historische Museum. Labor, Schaubühne, Identitätsfabrik. Frankfurt: Campus Verlag.

Corbin, Alain

1987 Backstage. I: M. Perrot (ed.): A History of Private Life IV. Cambridge, Mass.: Belknap Press of Harvard University Press.

Elsner, John \& Roger Cardinal (eds.)

1994 The Cultures of Collecting. London: Reaktion Books.

Foucault, Michel

1999 [1980] About the Beginning of the Hermeneutics of the Self. I: J. R. Carrette (ed.): Religion and Culture by Michel Foucault. Manchester University Press.

Gillis, John R

1996 A World of Their Own Making: Myth, Ritual, and the Quest for Family Values. New York: BasicBooks. 
Halbwachs, Maurice

1980 The Collective Memory. New York: Harper and Row.

Hebdige, Dick

1979 Subculture. The Meaning of Style. London: Methuen \& Co. Ltd.

Hoskins, Janet

1998 Biographical Objects. How Things Tell the Stories of People's Lives. New York and London:

Routledge.

Klein, Barbro

1995 Fragment och materialiserade minnen - om förmål, estetik och folklivsforskning. I: Daun (red.): Ting, kultur och mening. Stockholm: Nordiska Museets Förlag.

Kirshenblatt-Gimblett, Barbara

1989 Objects of Memory: Material Culture as Life Review. I: E. Oring (ed.): Folk Groups and

Folklore Genres. A Reader. Logan, Utah: Utah State University Press.

Kuntz, Andreas

1989 Biographie und biographisches Object zur Bedeutung von Erinnerungsgegenständen in Lebensgeschichtlichen Berichten. I: Bockhorn, Eberhart \& Zupfer (red.): Auf der Suche nach der verlorenen Kultur. Wien: Institut für Volkskunde der Universität Wien.

Kwint, Marius et al. (eds.)

1999 Material Memories. Design and Evocation. Oxford: Berg.

Lowenthal, David

$1993 \quad$ Memory and Oblivion. Museum Management and Curatorship 12.

Löfgren, Orvar

1992 Mitt liv som konsument. Livshistoria som forskningsstrategi och analysmaterial. I: C.

Tigerstedt, J. P. Roos \& A. Vilkko (red.): Självbiografi, kultur, liv. Levnadshistoriska studier inom human- och samhällsvetenskap. Stockholm: Brutus Östlings Bokförlag Symposion.

Miller, Daniel

1994 Artefacts and the Meaning of Things. I: T. Ingold (ed.): Companion Encyclopedia of Anthropology. London and New York: Routledge.

Nora, Pierre

1984 Les Lieux de Mémoire. Paris: Gallimard.

Otto, Lene

2001 Livshistorier og biografisk subjektivitet. Dansk pædagogisk Tidsskrift nr. 1:3-11.

Otto, Lene \& Lykke Pedersen

1997 Livshistorie - Livsforløbets Historie. Refleksioner over livet som udstillingstema. Nordisk Museologi 2:43-66.

1998 Collecting Oneself. Lifestories and Objects of Memory. Ethnologia Scandinavica 28:77-92.

Piaget, Jean

1992

Barnets psykiske udvikling. København: Hans Reitzel.

Pearce, Susan M

1995 On Collecting: An Investigation into Colleting in the European Tradition. London:

Routledge.

Rogan, Bjarne

1996 From Passion to Possessiveness. Collectors and Collecting in a Symbolic Perspective. Ethnologia Europae 26(1):65-79.

Schlereth, Thomas J

1992 Cultural History and Material Culture. Everyday Life, Landscapes, Museums.

Charlottesville, Va.h: University Press of Virginia. 
Stewart, Susan

1984

On Longing: Narratives of the Miniature, the Gigantic, the Souvenir, the Collection.

Baltimore and London: The Johns Hopkins University Press.

Warnier, Jean-Pierre

2001

A Praxeological Approach to Subjectivation in a Material World. Journal of Material Culture 6(1):5-24. 